- a selection pressure (selection intensity/generation interval ratio) of $35-45$ points on the boars according to the magnitude of the line;

- correct economic management depending on production of at least roo litters per year;

- less than I p. Ioo increase in the inbreeding coefficient per generation.

\title{
Utilization of a control herd \\ to estimate genetic change of fattening and carcass traits in the Large White breed in France from 1965 to 1973. A preliminary note
}

\author{
Y. HOUIX, P. DANDO* and P. SELLIER \\ Station de Génétique quantitative ct appliquée, I. N.R.A., C.N.R.Z., \\ 78350 Jouy en Josas \\ * Domaines Expérimentaux de la Sapinière et de Cralle, \\ Avord, 18800 Baugy
}

\begin{abstract}
No real control herd presently exists in lirance, but it secmed to be possible to consider as such an experimental herd kept at the "domaine de Galle " (I. N. R. A.) for another purpose. This Large. White herd, established in $1965^{\circ}$ with ro boars and $\mathrm{I} 20$ sows, was primarily used for a selection experiment on litter size at birth. Being not subjected to any selection on growth and carcass traits, the Galle herd could be considered as a control for these production traits, supposed to be genetically independent of the litter size. Available data consisted of measurements on 60 gilts from the Galle herd, tested in competition. with I 2 contemporary gilts from 26 selection herds of the Large White breed. Comparisons were made within-testing period for $\mathrm{I}_{4}$ traits. Results definitely show a favourable genetic trend of Large. White breed since 1965 , both for rate and economy of gain and for most of body-composition traits. The estimated genetic gain is around $7.5 \mathrm{~F}$ per year. Another point of concern is the unfavourable evolution of meat quality, particularly of ultimate $\mathrm{pH}$ of muscle. The genetic assumptions underlying the validity of this estimation of genetic change are discussed. A statistical analysis of a larger number of data is now in progress.
\end{abstract}

\section{A comparison of the crossbred progeny of French Landrace and Pietrain boars}

\author{
I'. SELLIER
}

Station de Génétique quantitative et appliquée, I. N.R. A., C.N.R.Z., 78350 Jouy en Josas

Both French Landrace and Pietrain boars were randomly used (by A. I.) on Landrace $\times$ Large White sows of commercial farms. Gilts and barrows sampled in resultant litters were sent to an experimental station where they were fer ad libitum (test started at $30 \mathrm{~kg}$ ) and slaughtered at 